\title{
Neuropeptide Y and Asthma Clinical Course
}

\author{
Yanina S. Shkatova; Andrey V. Budnevsky, PhD, ScD; \\ Evgeniy S. Ovsyannikov*, PhD, ScD; Galina G. Prozorova, PhD, ScD; \\ Anna P. Volynkina, PhD; Irina A. Olysheva, PhD \\ Voronezh State Medical University named after N. N. Burdenko \\ Voronezh, the Russian Federation
}

\begin{abstract}
Background: The spectrum of clinical manifestations and pathogenetic mechanisms of bronchial asthma (BA) is very wide. Given the complex pathogenesis and syndromic nature of BA, it is not surprising that there is no single universal biomarker. The objective of this study was to evaluate levels of neuropeptide Y (NPY) and its association with levels of leptin, adiponectin, oxidative damage, antioxidant status, spirometry parameters, and asthma control in BA patients.

Methods and Results: Overall, 140 patients [35(25\%) men and 105(75\%) women; mean age of 57.0土9.34 years] with moderate asthma participated in the study. According to body mass index, all patients were divided into three groups. The asthma diagnosis was based on the integral assessment of symptoms, medical history, health status, and spirometry values according to the Global Strategy for Asthma Management and Prevention. (GINA, 2017 REPORT). The Asthma Control Test (ACT) was used to assess asthma control. NPY was measured in blood serum in EIA.

The NPY level was significantly higher in overweight patients and patients with obesity than in patients with normal body weight. The NPY level significantly correlated with leptin ( $\mathrm{r}=0.44 ; P<0.05)$, adiponectin $(\mathrm{r}=-0.24 ; P<0.05)$, ImanOx $(\mathrm{r}=-0.40$; $P<0.05)$, PerOx $(\mathrm{r}=0.58 ; P<0.05)$, ACT $(\mathrm{r}=-0.41 ; P<0.05)$, VC (r=-0.31; $P<0.05)$, FEV1 (r=-0.41; $P<0.05)$, FEF 25\% $(\mathrm{r}=-0.26$; $P<0.05)$, FVC ( $\mathrm{r}=-0.23 ; P<0.05)$, Tiffno index $(\mathrm{r}=-0.36 ; P<0.05)$, FEF $50 \%(\mathrm{r}=-0.22 ; P<0.05)$, and $\mathrm{PEF}(\mathrm{r}=-0.23 ; P<0.05)$

Conclusion: The severity of the asthma clinical course is associated with different factors, including oxidative stress, levels of leptin, adiponectin and NPY. NPY seems to be associated with worse asthma control and higher levels of leptin and oxidative damage.(International Journal of Biomedicine. 2021;11(4):410-413.)
\end{abstract}

Key Words: asthma control $\bullet$ oxidative stress $\bullet$ neuropeptide $\mathrm{Y} \bullet$ adipokines

For citation: Shkatova YaS, Budnevsky AV, Ovsyannikov ES, Prozorova GG, Volynkina AP, Olysheva IA. Neuropeptide Y and Asthma Clinical Course. International Journal of Biomedicine. 2021;11(4):410-413. doi:10.21103/Article11(4)_OA2

\section{Abbreviations}

ACT, Asthma Control Test; BA, bronchial asthma; BMI, body mass index; BW, body weight; $\mathbf{F E V}$, forced expiratory volume in 1 sec; FEF, forced expiratory flow; FVC, forced vital capacity; NPY, neuropeptide Y; OS, oxidative stress; PEF, peak expiratory flow; TAS, total antioxidant status; TOD, total oxidative damage; VC, vital capacity; WC, waist circumference.

\section{Introduction}

Bronchial asthma (BA) is a disease that combines several syndromes characterized by inflammation, hyperresponsiveness,

*Corresponding author: Evgeniy S. Ovsyannikov, $P h D, S c D$. Department of faculty therapy, Voronezh State Medical University named after N.N.Burdenko.Voronezh, Russia.E-mail: ovses@yandex.ru and intermittent airway obstruction. ${ }^{(1)}$ The spectrum of clinical manifestations and pathogenetic mechanisms of BA is very wide. ${ }^{(2)}$ In this regard, the approach to treatment methods cannot be standardized and applicable over a long period of time for all patients. ${ }^{(3)}$ In addition to the generally accepted methods for an objective assessment of the clinical course of BA (detection of a viral infection and allergen), there are insufficiently known and not widely used methods. These methods are aimed at identifying other triggers that exacerbate the disease. In most 
cases, deterioration in asthma is associated with an increase in the inflammatory process in the airways. ${ }^{(4,5)}$ Therefore, the measurement of markers of this inflammation will make it possible to clearly differentiate clinically similar phenotypes and to adequately adjust the treatment. Given the complex pathogenesis and syndromic nature of BA, it is not surprising that there is no single universal biomarker. Thus, the search for new biomarkers and factors affecting the course and control of asthma remains essential. One of the less-studied potential asthma biomarkers is neuropeptide Y (NPY). Several studies have reported that certain genotypes of NPY are associated with asthma and that Y1 receptors for NPY play an important role in allergic airway inflammation. ${ }^{(6)}$ There is also evidence that during exacerbations of asthma, levels of NPY increase. ${ }^{(7)}$

The objective of this study was to evaluate levels of NPY and its association with levels of leptin, adiponectin, oxidative damage, antioxidant status, spirometry parameters, and asthma control in BA patients.

\section{Materials and Methods}

Overall, 140 patients [35(25\%) men and 105(75\%) women; mean age of 57.0 \pm 9.34 years] with moderate asthma participated in the study. According to body mass index, all patients were divided into three groups. Group 1 included 46 patients with normal body weight; Group 2 included 46 overweight patients; Group 3 included 48 patients with obesity.

The asthma diagnosis was based on the integral assessment of symptoms, medical history, health status, and spirometry values according to the Global Strategy for Asthma Management and Prevention (GINA, 2017 REPORT). All patients received standard asthma therapy.

Excluded criteria were asthma exacerbation, tuberculosis, chronic kidney disease, permanent atrial fibrillation, acute myocardial infarction and any other acute conditions, cancer, pregnancy and lactation, infectious diseases, mental illness.

The study was approved by the Ethics Committee of Voronezh State Medical University named after N.N. Burdenko. Written informed consent was obtained from each patient.

The Asthma Control Test (ACT) was used to assess asthma control. Lung function was assessed with spiroanalizer "Diamant-c" (Russia). Automatic ELISA analyzer Chemwell ELISA (Awareness Technology, USA) was used for testing the serum levels of leptin and adiponectin using reagent kits (MEDIAGNOST GMBH, GERMANY). NPY was measured in blood serum in EIA (BCM Diagnostics). The determination of TOD was carried out with use of a reagent kit to determine the degree of TOD to biological molecules (PerOx (TOS) (Oxidative Capacity)). We determined the overall antioxidant status by using reagents for determining TAS (ImAnOx (TAS) (Antioxidative Capacity)).

All data was evaluated with STATGRAPHICS Plus 5.1. The normality of the distribution of continuous variables was tested by the one-sample KolmogorovSmirnov test. For data with normal distribution, intergroup comparisons were performed using Student's t-test. Group comparisons with respect to categorical variables are performed using the chi-square test. A probability value of $P<0.05$ was considered statistically significant. The Bonferroni correction $(0.05 / 3=0.017)$ was used for multiple comparisons adjustments.

\section{Results}

The studied groups did not differ significantly in a number of social and demographic parameters and, therefore, could be used for a comparative assessment. Group 3 patients had the highest leptin levels while Group 1 patients had the highest adiponectin levels. The leptin level was significantly higher in Group 3 than in Group $1(P<0.0001)$, while the adiponectin level was significantly higher in Group 1 than in Group $3(P<0.0001)$. The TAS value was significantly higher in Group 1 than in Groups 2 and $3(P<0.0001)$. The value of TOD in Group 1 was significantly lower than in Group 3 $(P<0.0001)$ (Table 1$)$. The NPY level was significantly lower in Group 1 than in Groups 2 and $3(P<0.0001)$. Disease control was not achieved in any of the three groups, but there was a statistically significant difference in ACT scores between Groups 1 and Groups 2 and $3(P<0.017)$ (Table 2).

Table 1.

Adipokines levels and oxidant/antioxidant status in the study groups

\begin{tabular}{|c|c|c|c|c|}
\hline Variable & $\underset{(\mathrm{n}=46)}{\text { Group } 1}$ & $\begin{array}{c}\text { Group } 2 \\
(\mathrm{n}=46)\end{array}$ & $\begin{array}{c}\text { Group } 3 \\
(\mathrm{n}=48)\end{array}$ & Statistics \\
\hline $\begin{array}{l}\text { Leptin, } \\
\mathrm{ng} / \mathrm{ml}\end{array}$ & $9.44 \pm 4.32$ & $12.21 \pm 4.01$ & $22.16 \pm 8.53$ & $\begin{array}{l}\mathrm{P}_{1-2}=0.0020 \\
\mathrm{P}_{2-3}<0.0001 \\
\mathrm{P}_{1-3}<0.0001\end{array}$ \\
\hline $\begin{array}{l}\text { Adipo- } \\
\text { nectin, } \\
\mu \mathrm{g} / \mathrm{ml}\end{array}$ & $21.83 \pm 5.65$ & $19.16 \pm 6.02$ & $16.32 \pm 4.30$ & $\begin{array}{l}\mathrm{P}_{1-2}=0.0309 \\
\mathrm{P}_{2-3}=0.0097 \\
\mathrm{P}_{1-3}<0.0001\end{array}$ \\
\hline $\begin{array}{l}\text { TOD, } \\
\mu \mathrm{mol} / 1\end{array}$ & $832.19 \pm 321.13$ & $1031.27 \pm 291.36$ & $1455.48 \pm 630.53$ & $\begin{array}{l}\mathrm{P}_{1-2}=0.0025 \\
\mathrm{P}_{2-3}=0.0001 \\
\mathrm{P}_{1-3}<0.0001\end{array}$ \\
\hline $\begin{array}{l}\mathrm{TAS}, \\
\mu \mathrm{mol} / 1\end{array}$ & $524.08 \pm 93.29$ & $285.68 \pm 46.71$ & $257.25 \pm 59.47$ & $\begin{array}{l}\mathrm{P}_{1-2}<0.0001 \\
\mathrm{P}_{2-3}=0.0118 \\
\mathrm{P}_{1-3}<0.0001\end{array}$ \\
\hline
\end{tabular}

Table 2.

ACT score and NPY levels in the study groups

\begin{tabular}{|c|c|c|c|c|}
\hline Variable & $\begin{array}{c}\text { Group 1 } \\
\mathrm{n}=46\end{array}$ & $\begin{array}{c}\text { Group 2 } \\
\mathrm{n}=46\end{array}$ & $\begin{array}{c}\text { Group 3 } \\
\mathrm{n}=48\end{array}$ & Statistics \\
\hline NPY, ng/ml & $0.30 \pm 0.12$ & $0.47 \pm 0.10$ & $0.71 \pm 0.20$ & $\begin{array}{l}\mathrm{P}_{1-2}<0.0001 \\
\mathrm{P}_{2-3}<0.0001 \\
\mathrm{P}_{1-3}<0.0001\end{array}$ \\
\hline ACT, points & $18.33 \pm 3.74$ & $15.61 \pm 4.45$ & $13.60 \pm 5.01$ & $\begin{array}{l}\mathrm{P}_{1-2}=0.0021 \\
\mathrm{P}_{2-3}=0.0429 \\
\mathrm{P}_{1-3}<0.0001\end{array}$ \\
\hline
\end{tabular}

The NPY level significantly correlated with leptin $(\mathrm{r}=0.44 ; P<0.05)$, adiponectin $(\mathrm{r}=-0.24 ; P<0.05)$, ImanOx $(\mathrm{r}=-0.40 ; P<0.05)$, PerOx $(\mathrm{r}=0.58 ; P<0.05)$, ACT $(\mathrm{r}=-0.41$; $P<0.05), \mathrm{VC}(\mathrm{r}=-0.31 ; P<0.05), \mathrm{FEV} 1(\mathrm{r}=-0.41 ; P<0.05), \mathrm{FEF}$ $25 \%(\mathrm{r}=-0.26 ; P<0.05)$, forced vital capacity (FVC) $(\mathrm{r}=-0.23$; 
$P<0.05)$, Tiffno index $(\mathrm{r}=-0.36 ; P<0.05)$, FEF $50 \%(\mathrm{r}=-0.22$; $P<0.05)$, and PEF $(\mathrm{r}=-0.23 ; P<0.05)$

\section{Discussion}

In recent years, special attention has been paid to NPY, due to the extensive effects in the human body carried out through the Y1, Y2, Y3, Y4, Y5, Y6 receptors, namely, participation in regulating appetite, cardiovascular system, stress, cognitive processes. ${ }^{(8-12)}$ The NPY value for the respiratory system is also being investigated. Li et al.,(6) in their experimental study in mice, showed that NPY produced by the airway epithelium causes smooth muscle contraction, contributing to airway hyperresponsiveness. According to an experimental study by Thangaratnarajah et al., NPY affects the intrauterine formation of alveoli in mice and regulates the proliferation and migration of myofibroblasts. ${ }^{(13)}$ Macia et al. ${ }^{(14)}$ also showed that NPY, the release of which is greatly enhanced during stress, exacerbates allergic airway inflammation in mice via its Y1 receptor. Their data indicate that the development of allergic airway inflammation was associated with increased NPY expression in the lungs and that the absence of NPY-mediated signaling in mice, due to the absence of NPY or its Y1 receptor in mice, led to a significant reduction in inflammation. Makinde et al. ${ }^{(15)}$ also studied the role of NPY and its receptors for allergic inflammation in the airways using mice. Expression of NPY was localized in macrophage-like cells in the peribronchial and perivascular regions of the lung tissue. Receptors Y1 and Y5 were expressed by both structural and inflammatory cells of lung tissue. Thus, the authors concluded that NPY produced by activated macrophage-like cells can participate in regulating cytokine production and cellular activity of immune cells. ${ }^{(15)}$ A small number of clinical studies have also investigated the relationship between NPY and asthma. Lu et al. ${ }^{(16)}$ investigated the relationship between the five most common genotypes of the $N P Y$ gene and the presence of asthma. The study included 126 patients with asthma without concomitant chronic pathology and 182 healthy volunteers who constituted the control group (aged 21-35 years). The study revealed that the CT genotype of rs5574 and the GT genotype of rs17149106 are interrelated with the presence of asthma. Lu et al. ${ }^{(17)}$ also studied patients with an established diagnosis of asthma at the time of exacerbation, patients $(n=51)$ with a stable course of asthma aged 21-35 years, as well as a control group $(\mathrm{n}=69)$ corresponding to the patients in gender and age. The data obtained by the authors allowed them to conclude that the presence of psychological stress in patients with asthma leads to an increase in the response of type 2 T-helpers, and this effect may be mediated by the NPY level in the blood. ${ }^{(17)}$ Cardell et al. ${ }^{(18)}$ conducted a comparative study of the levels of several neuropeptides (vasoactive intestinal peptide, substance $\mathrm{P}$, neuropeptide $\mathrm{Y}$, calcitonin-genelinked peptide) in the blood of patients with asthma during an exacerbation in comparison with the control group. The NPY level did not correlate in any way with the reversibility of obstruction; however, NPY level was increased during exacerbation, compared to healthy subjects. ${ }^{(18)}$ Despite the small number of studies investigating the relationship between NPY and asthma, there are results indicating a negative effect of NPY on the clinical course of asthma and airway inflammation. In our study, NPY was associated with higher oxidative damage, higher leptin levels, worse asthma control and lower adiponectin and antioxidant levels. The importance of leptin and OS for the asthma course has been shown in numerous studies, as they lead to a worse clinical course of the disease. ${ }^{(19-2)}$ The antioxidant system and adiponectin were shown to have protective effects in asthma. ${ }^{(23,24)}$

In conclusion, the severity of the asthma clinical course is associated with different factors, including OS, levels of leptin, adiponectin and NPY. NPY seems to be associated with worse asthma control and higher levels of leptin and oxidative damage.

\section{Competing Interests} interests.

The authors declare that they have no competing

\section{Disclaimers}

The views expressed in this article are the author's own and do not reflect the official position of the institution.

\section{References}

1. Ermolova AV, Budnevsky AV, Yu ME, Ovsyannikov ES, Drobysheva ES. [BRONCHIAL ASTHMA AND METABOLIC SYNDROME]. Klin Med (Mosk). 2015;93(6):44-9. [Article in Russian].

2. Kozhevnikova SA, Budnevskiy AV, Ovsyannikov ES, Belov VN. [Particularity of the clinical course and quality of life of patients with chronic obstructive pulmonary disease on the background of the metabolic syndrome]. Medical News of North Caucasus. 2017;12(1):20-23. doi:10.14300/ mnnc.2017.12006. [Article in Russian].

3. Budnevsky AV, Isaeva YV, Malysh EY, Kozhevnikova SA. [Pulmonary rehabilitation as an effective method for optimizing therapeutic and preventive measures in patients with chronic obstructive pulmonary disease concurrent with metabolic syndrome]. Ter Arkh. 2016;88(8):25-29. doi: 10.17116/terarkh201688825-29. [Article in Russian].

4. Provotorov VM, Budnevsky AV, Filatova YI. [Clinical manifestations of asthma during combination therapy using ceruloplasmin]. Ter Arkh. 2016;88(3):36-39. doi: 10.17116/ terarkh201688336-39. [Article in Russian].

5. Provotorov VM, Budnevsky AV, Filatova YI, Perfil'eva MV. [ANTIOXIDANT THERAPY OF BRONCHIAL ASTHMA]. Klin Med (Mosk). 2015;93(8):19-22. [Article in Russian].

6. Li S, Koziol-White C, Jude J, Jiang M, Zhao H, Cao G, Yoo E, Jester W, Morley MP, Zhou S, Wang Y, Lu MM, Panettieri RA Jr, Morrisey EE. Epithelium-generated neuropeptide $\mathrm{Y}$ induces smooth muscle contraction to promote airway hyperresponsiveness. J Clin Invest. 2016 May 2;126(5):197882. doi: $10.1172 /$ JCI81389.

7. Cardell LO, Uddman R, Edvinsson L. Low plasma concentrations of VIP and elevated levels of other neuropeptides during exacerbations of asthma. Eur Respir J. 1994 Dec;7(12):2169-73. doi: 10.1183/09031936.94.07122169.

8. Shende P, Desai D. Physiological and Therapeutic Roles 
of Neuropeptide Y on Biological Functions. Adv Exp Med Biol. 2020;1237:37-47. doi: 10.1007/5584 2019427.

9. Hofmann S, Bellmann-Sickert K, Beck-Sickinger AG. Chemical modification of neuropeptide $\mathrm{Y}$ for human $\mathrm{Y} 1$ receptor targeting in health and disease. Biol Chem. 2019 Feb 25;400(3):299-311. doi: 10.1515/hsz-2018-0364.

10. Domin H. Neuropeptide Y Y2 and Y5 receptors as potential targets for neuroprotective and antidepressant therapies: Evidence from preclinical studies. Prog Neuropsychopharmacol Biol Psychiatry. 2021 Dec 20;111:110349. doi: 10.1016/j.pnpbp.2021.110349.

11. Lin ST, Li YZ, Sun XQ, Chen QQ, Huang SF, Lin S, Cai SQ. Update on the Role of Neuropeptide Y and Other Related Factors in Breast Cancer and Osteoporosis. Front Endocrinol (Lausanne). 2021 Aug 6;12:705499. doi: 10.3389/ fendo.2021.705499.

12. Zheng YL, Wang WD, Li MM, Lin S, Lin HL. Updated Role of Neuropeptide $\mathrm{Y}$ in Nicotine-Induced Endothelial Dysfunction and Atherosclerosis. Front Cardiovasc Med. 2021 Feb 23;8:630968. doi: 10.3389/fcvm.2021.630968.

13. Thangaratnarajah C, Dinger K, Vohlen C, Nawabi J, Lopez EG, Dobner J, et al. Novel NPY-mediated migratory effect on pulmonary fibroblasts and on IL-6 expression is related to accelerated lung growth after intrauterine growth restriction. Neuropeptides. 2016;55:11-2. doi: 10.1016/j.npep.2015.11.030. 14. Macia L, Rao PT, Wheway J, Sierro F, Mackay F, Herzog H. Y1 signalling has a critical role in allergic airway inflammation. Immunol Cell Biol. 2011 Nov;89(8):882-8. doi: 10.1038/icb.2011.6.

15. Makinde TO, Steininger R, Agrawal DK. NPY and NPY receptors in airway structural and inflammatory cells in allergic asthma. Exp Mol Pathol. 2013 Feb;94(1):45-50. doi: 10.1016/j.yexmp.2012.05.009.

16. Lu Y, Andiappan AK, Lee B, Ho R, Lim TK, Kuan WS, Goh DY, Mahadevan M, Sim TB, Wang Y, Van Bever HP, Rotzschke O, Larbi A, Ng TP. Neuropeptide Y associated with asthma in young adults. Neuropeptides. 2016 Oct;59:117-121. doi: 10.1016/j.npep.2016.07.003.

17. Lu Y, Van Bever HP, Lim TK, Kuan WS, Goh DY, Mahadevan M, Sim TB, Ho R, Larbi A, Ng TP. Obesity, asthma prevalence and IL-4: Roles of inflammatory cytokines, adiponectin and neuropeptide Y. Pediatr Allergy Immunol. 2015 Sep;26(6):530-6. doi: 10.1111/pai.12428.

18. Cardell LO, Uddman R, Edvinsson L. Low plasma concentrations of VIP and elevated levels of other neuropeptides during exacerbations of asthma. Eur Respir J. 1994 Dec;7(12):2169-73. doi: 10.1183/09031936.94.07122169.

19. Zhang L, Yin Y, Zhang H, Zhong W, Zhang J. Association of asthma diagnosis with leptin and adiponectin: a systematic review and meta-analysis. J Investig Med. 2017 Jan;65(1):5764. doi: 10.1136/jim-2016-000127.

20. Kurokawa A, Kondo M, Arimura K, Ashino S, Tagaya E. Less airway inflammation and goblet cell metaplasia in an IL-33-induced asthma model of leptin-deficient obese mice. Respir Res. 2021 Jun 1;22(1):166. doi: 10.1186/s12931-02101763-3.

21. Carpagnano GE, Scioscia G, Lacedonia D, Soccio P, Quarato CMI, Cotugno G, Palumbo MG, Foschino Barbaro MP. Searching for Inflammatory and Oxidative Stress Markers Capable of Clustering Severe Asthma. Arch Bronconeumol (Engl Ed). 2021 May;57(5):338-344. English, Spanish. doi: 10.1016/j.arbres.2020.04.024.

22. Mishra V, Banga J, Silveyra P. Oxidative stress and cellular pathways of asthma and inflammation: Therapeutic strategies and pharmacological targets. Pharmacol Ther. 2018 Jan;181:169-182. doi: 10.1016/j.pharmthera.2017.08.011. 23. Otelea MR, Arghir OC, Zugravu C, Rascu A. Adiponectin and Asthma: Knowns, Unknowns and Controversies. Int J Mol Sci. 2021 Aug 20;22(16):8971. doi: 10.3390/ijms22168971.

24. Karadogan B, Beyaz S, Gelincik A, Buyukozturk S, Arda N. Evaluation of oxidative stress biomarkers and antioxidant parameters in allergic asthma patients with different level of asthma control. J Asthma. 2021 Jan 8:1-15. doi: 10.1080/02770903.2020.1870129. 